\title{
A newly developed assessment tool on collaborative role of doctor-pharmacist in patient medication management
}

\author{
Nowo opracowane narzędzie oceny współpracy lekarza i farmaceuty \\ w opiece farmaceutycznej nad pacjentem
}

MAYUR PORWAL 1, A, E, LOKPAL SINGH ${ }^{2, \text { B }}$, ARVIND KUMAR ${ }^{2, \text { B-D }}$, VAIBHAV RASTOGI', B-D, KAMAL K. MAHESHWARI ${ }^{3, A}$, D, F, SAURABH SHARMA, D

${ }^{1}$ IFTM University, Moradabad, Uttar Pradesh, India

${ }^{2}$ School of Pharmaceutical Sciences, IFTM University, Moradabad, Uttar Pradesh, India

${ }^{3}$ Department of Pharmacy, Rohilkhand University, Bareilly, Uttar Pradesh, India

${ }^{4}$ Department of Pharmacy, Vivek College of Technical Education, Bijnor, Uttar Pradesh, India

A - Study Design, B - Data Collection, C - Statistical Analysis, D - Data Interpretation, E - Manuscript Preparation, $\mathbf{F}$ - Literature Search, $\mathbf{G}$ - Funds Collection

Summary Background. Poor communication is one of the most important common factor contributing to medication errors. Despite their common history, there are many intellectual and practical differences between the professions of medicine and pharmacy that eventually affects patient care and health outcomes.

Objectives. The main objective of the study is to evaluate the coordination and teamwork between pharmacist and doctor to provide betterment in the care of the patient health.

Material and methods. A questionnaire of 10 questions was developed each for the patient, pharmacist and doctor posted on District Hospital, Moradabad (U.P.), India and data collected from the patient and medical professionals through questionnaire were analyzed for collaborative role of doctor-pharmacist with respect to patient care. The results were analyzed using Graph Pad Prism 5.

Results. The data obtained from the questionnaire highlights a significant effort between pharmacist and doctors. However, some patients often doubt in the skills of pharmacist for treatment outcome, but the majority of people responds positive to doctor-pharmacist role as they prove to be fruitful in removing medication errors.

Conclusions. To facilitate the patient care, doctor-pharmacist alliance is necessary, desired and should be motivated as professed by the respondents. Collaboration is an important element of effective patient-focused health care delivery.

Key words: questionnaire, pharmacist, doctor, communication.

Streszczenie Wstęp. Zła komunikacja jest jednym z najważniejszych, częstych czynników wpływających na błędy w przyjmowaniu leków. Mimo że mają wspólną historię, istnieje wiele intelektualnych i praktycznych różnic w zawodzie lekarza i farmaceuty, które dotyczą opieki i zdrowia pacjentów.

Cel pracy. Ocena koordynacji i współpracy lekarza i farmaceuty mająca na celu poprawę zdrowia pacjenta.

Materiał i metody. Opracowano kwestionariusz składający się z 10 pytań odpowiednio dla pacjenta, farmaceuty i lekarza w Szpitalu Rejonowym w Moradabad w Indiach. Następnie zebrane dane były analizowane pod kątem wspólnej roli lekarza i farmaceuty w odniesieniu do opieki nad pacjentem. Analizę przeprowadzono za pomocą programu Graph Pad Prism 5. Wyniki. Dane uzyskane z kwestionariusza podkreślają istotną współpracę między farmaceutą a lekarzem. Niektórzy pacjenci podają w wątpliwość wiedzę farmaceuty, ale większość ludzi akceptuje współpracę lekarza i farmaceuty, ponieważ okazuje się owocna w usuwaniu błędów w leczeniu.

Wnioski. Aby ułatwić opiekę nad pacjentem, współpraca lekarza i farmaceuty jest konieczna, pożądana i powinna być wspierana, jak oceniają respondenci. Współpraca jest ważnym elementem dostarczania skutecznej opieki medycznej zorientowanej na pacjenta.

Słowa kluczowe: kwestionariusz, farmaceuta, lekarz, komunikacja.

\section{Background}

Collaboration, teamwork and good communication between health professionals are important for the safe and efficient delivery of health care [1]. Collaborative care is the most common, but the terms multidisciplinary, inter-professional, shared or team care, while do not mean the same, is often used interchangeably by health professionals. For the past 10 years, the role of pharmacists in the community has been lingering with the provision of many professional services including medication reviews, hypertension, diabetes and asthma and many more diseases management programs with patient medication profiles. It is in the supplementary role of managing therapy, in collaboration with prescribers, that pharmacists can now make a fruitful contribution to patient care. To do so, the role of the pharmacist needs to be redefined and reoriented. Pharmacists need to pay more 
attention to patient-centered, outcomes-focused care to optimize the safe and effective use of medicines [2].

Studies that have integrated pharmacists into primary care practices have shown improved patient outcomes [3]. Collaborative models have improved the treatment of hypertension [4]. Pharmacists have the potential to take full advantage of drug therapy by identifying medication-therapy problems and recommending solutions [5]. Physicians are interested to such recommendations $[6,7]$.

Doctor-pharmacist teamwork improves prescription quality through [8] increased effectiveness and well-being. A growing body of experimental studies has demonstrated the impact of integrating pharmacist in practice-based teamwork interventions that improve healthcare processes and outcomes $[9,10]$. Doctor-pharmacist collaborative work has improved and optimized treatment outcomes in hypertension, heart failure, pain [11] management, chronic dermatologic conditions, diabetes mellitus, cancer management, asthma, peptic ulcer disease and dyslipidemia [12].

\section{Objectives}

This study aims to determine and document the perception of patients, doctors and pharmacists on collaboration between doctors and pharmacists.

\section{Material and methods}

The study employed a descriptive survey method to determine the perceptions of the respondents on collaboration between the doctors and pharmacists in patient management in the District Hospital, Civil lines, Moradabad, Uttar Pradesh, India, is using pre-tested self administered questionnaires. A synopsis of the study were submitted to the hospital administration for its approval with clearly focussing its aim and importance. Later it was approved by the administration. Patients were informed with the objectives of the study, and their were considered consented to participate when they returned the completed survey. The questionnaire was also pretested in the private clinic (50 bed) situated near the university campus.

The District Hospital is a tertiary health institution with a bed capacity of 500 (400 adult and 100 children) and staff strength of over 150 personnel consisting of Pharmacists (09) and Doctors (55) with an average daily patient flow or visits of about 176 per day. Separate questionnaires were designed to get the perceptions of the respondents (patients, doctors and pharmacist) on Physician-Pharmacist collaboration in practice.

The questionnaire (consisting of 10 questions) each of the patients (100) sought to obtain demographic information on each patient as well as their responses to the research question, including perception of roles and satisfaction with services provided by Doctors and Pharmacists, as well as actual collaboration between Doctors and Pharmacists. The questionnaire (10 questions) for doctors sought to obtain their demographic information (areas of specialty, years of practice, qualifications, etc.) and responses to the research questions $[13,14]$.

The questionnaire (10 questions) for each pharmacist (09) sought to obtain their demographic information (rank, years of practice, qualifications etc.) and responses to the research questions.

\section{Target Population/Sample Size}

The required sample size for the persons to be included in this study was determined to employ a mathematical formula (Slovin's formula) for calculating sample size as below:

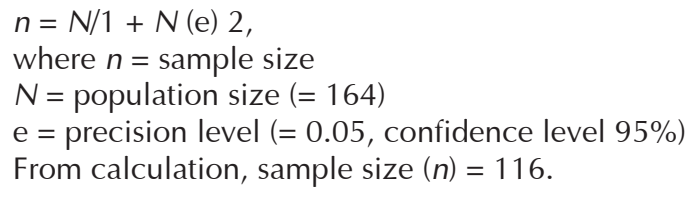

The study population, therefore, included all the doctors, all the pharmacists and patients (total 164) made up of adult inpatients and out-patients who visited the hospital within the study period and consented to take part in the study. For obtaining response, a three-point rating scale was used. The perception score is calculated according to the Theory of Planned Behavior (TPB) with the following factors taken into the consideration like-attitude of doctor-pharmacist towards collaboration, belief by patients towards collaboration, perceived behavior control (extent of collaboration).

\section{Data Analysis}

The data obtained from the questionnaires were sorted, coded and analyzed using a computer based analysis software called Graph Pad Prism 5. Data analysis involved bivariate statistics (mean, t-test and ANOVA). A descriptive statistical analysis for all the questionnaire items was carried out.

\section{Results}

The requisite sample size of the persons to be included in this study was calculated by Slovin's formula as 116 with a confidence level of $95 \%$ and precision error of 0.05 . A total of 164 questionnaires were administered (100 patients, 55 doctors and 09 pharmacists) as determined above out of which 150 were completed and returned giving an overall response rate of $91.14 \%$. The whole study analysis was completed in approximately 6 months duration.

\section{Patients}

The occupational frequency distribution of the patients was students $(30.5 \%)$, unemployed $(9.5 \%)$, private business $(16.5 \%)$ and civil servants (43.5\%). The distribution of educational status was primary education (2\%), secondary education (28.5\%), National Diploma/National Certificate of Education $(39.5 \%)$, graduate $(28.5 \%)$ and postgraduate $(1.5 \%)$ with the gender distribution of male $(49 \%)$ and female $(51 \%)$. The descriptive statistics for age (group) of the patients revealed ages $18-24$ years $(16.5 \%), 25-30$ years $(30.5 \%), 31-35$ years $(20.5 \%), 36-40$ years $(12 \%), 41-45$ years $(7 \%), 46-50$ years $(4 \%), 51-55$ years $(4 \%)$ and $56-60$ years $(5.5 \%)$. The responses of the patients to the research questions are as summarized in Table 1.

\section{Doctors}

The distribution of the doctors based on their specialty or area of practice was; family medicine $(34.5 \%)$, surgery $(20.7 \%)$, pediatrics $(19 \%)$, obstetrics and gynecology $(17.2 \%)$, ophthalmology $(5.2 \%)$ and psychiatry (3.4\%), whereas the distribution based on position or rank was; Interns or House officers (19\%), Medical officers (12.1\%), Residents (32.8\%) and Consultants (36.2\%). The distribution based on the number of years in practice of the doctors, which were grouped revealed $6-10$ years (25.9\%), $11-15$ years $(45.6 \%), 16-20$ years $(17.2 \%)$ and 21 years and above (10.3\%). The distribution based on educational status was; graduate or first degree $(36.2 \%)$ and postgraduate $(63.8 \%)$ with a gender distribution of male $(86.2 \%)$ and female $(13.8 \%)$. The responses of the doctors to the research questions are as summarized in Table 2. 


\begin{tabular}{|c|l|l|l|l|}
\hline \multicolumn{2}{|l|}{ Table 1. Patients' responses to the research questions } & $\begin{array}{l}\text { Agree (AG) } \\
(\%)\end{array}$ & $\begin{array}{l}\text { Disagree (DG) } \\
(\%)\end{array}$ & $\begin{array}{l}\text { Can't say (N) } \\
(\%)\end{array}$ \\
\hline S.no. & Questions & 95.5 & 4.1 & 0.4 \\
\hline 1. & Do you have confidence in doctors? & 85.6 & 10.5 & 3.9 \\
\hline 2. & Do you have confidence in pharmacist? & 88.7 & 10.8 & 0.5 \\
\hline 3. & Are you satisfied with the care received from the doctor? & 74.6 & 18.3 & 7.09 \\
\hline 4. & Are you satisfied with the care received from the pharmacist? & 60.4 & 39.3 & 0.3 \\
\hline 5. & Have the doctors visited alone? & 38.4 & 67.2 & 5.6 \\
\hline 6. & Have the doctors visited with the pharmacist? & 52.1 & 49.5 \\
\hline 7. & $\begin{array}{l}\text { Do doctors and pharmacists collaboratively share their attention } \\
\text { towards your treatment? }\end{array}$ & 86.3 & 13.3 & 0.4 \\
\hline 8. & Does doctors and pharmacists collaboration be encouraged? & 95.4 & 3.3 & 1.3 \\
\hline 9. & Will collaboration improve service quality and well-being? & 10.2 & 88.3 & 1.4 \\
\hline 10. & Will collaboration waste time and add to treatment cost? & & \\
\hline
\end{tabular}

\begin{tabular}{|c|l|l|l|l|}
\hline \multicolumn{2}{|l|}{ Table 2. Doctors' responses to the research questions } \\
\hline S.no. & Questions & $\begin{array}{l}\text { Agree (AG) } \\
(\%)\end{array}$ & $\begin{array}{l}\text { Disagree (DG) } \\
(\%)\end{array}$ & $\begin{array}{l}\text { Can't say (N) } \\
(\%)\end{array}$ \\
\hline 1. & Do you have confidence in pharmacist? & 86.1 & 9.1 & 4.8 \\
\hline 2. & Do you enjoy working relationship with pharmacists? & 87.3 & 12.2 & 0.5 \\
\hline 3. & Do pharmacists share in responsibility of patient management? & 75.1 & 15.7 & 9.2 \\
\hline 4. & Do you collaborate with pharmacists in patient management? & 71.2 & 20.3 & 8.5 \\
\hline 5. & Does collaboration will improve treatment outcome? & 96.1 & 2.3 & 1.6 \\
\hline 6. & Is pharmacist's role equally important in patient management? & 71.1 & 19.5 & 9.4 \\
\hline 7. & Is collaboration necessary and should be encouraged? & 89.5 & 8.5 & 2 \\
\hline 8. & Will collaboration improve service quality? & 89.2 & 8.8 & 2 \\
\hline 9. & Will collaboration improve interdisciplinary relationship? & 87.3 & 8.5 & 4.2 \\
\hline 10. & Will collaboration waste time and add to treatment costs? & 12.2 & 84.4 & 3.4 \\
\hline
\end{tabular}

\begin{tabular}{|c|l|l|l|l|}
\hline \multicolumn{2}{|l|}{ Table 3. Pharmacists' responses to the research questions } & $\begin{array}{l}\text { Agree (AG) } \\
(\%)\end{array}$ & $\begin{array}{l}\text { Disagree (DG) } \\
(\%)\end{array}$ & $\begin{array}{l}\text { Can't say (N) } \\
(\%)\end{array}$ \\
\hline S.no. & Questions & 78.3 & 18.8 & 2.9 \\
\hline 1. & Do you have confidence in doctors? & 84.1 & 14.8 & 1.1 \\
\hline 2. & Do you enjoy working relationship with doctors? & 80.1 & 16.2 & 3.7 \\
\hline 3. & Do doctors share in responsibility of patient management? & 84.2 & 13.2 & 2.6 \\
\hline 4. & Do you collaborate with doctors in patient management? & 87.2 & 10.2 & 2.6 \\
\hline 5. & Will collaboration improve treatment outcome? & 88.2 & 9.1 & 2.7 \\
\hline 6. & Do doctors role equally important in patient management? & 87.3 & 6.6 & 6.1 \\
\hline 7. & Is collaboration necessary and should be encouraged? & 87.5 & 7.7 & 4.8 \\
\hline 8. & Will collaboration improve service quality? & 91.1 & 6.4 & 2.5 \\
\hline 9. & Will collaboration improve interdisciplinary relationship? & 16.1 & 89.3 & 5.4 \\
\hline 10. & Will collaboration waste time and add to treatment costs? & & \\
\hline
\end{tabular}

\section{Pharmacists}

The distribution frequency based on position or rank for the pharmacists was Pharmacist 1 (36.1\%), Senior Pharmacist (33.4\%), Principal Pharmacist (13\%), Chief Pharmacist (13\%) and Director of Pharmaceutical Services (4.3\%). The distribution based on the number of years in practice which were grouped was; $1-5$ years $(39.1 \%), 6-10$ years $(26.1 \%)$, $11-15$ years $(21.7 \%)$, and $16-20$ years $(13 \%)$. The distribution based on educational status was a graduate or first degree $(91.3 \%)$ and postgraduate $(8.7 \%)$ while the gender distribution was male $(69.6 \%)$ and female $(30.4 \%)$. The re- sponses of the doctors to the research questions are as summarized in Table 3.

From the t-test (Table 4) there was no significant difference between the general perception of doctors and pharmacists on the doctor-pharmacist role in patient management.

From the one way ANOVA (Table 5), there was a significant difference in the perception of patients, doctors and pharmacists on the influence of doctor-pharmacist collaboration on treatment outcome. There is also no difference in the perception of patient, doctor and pharmacist over the collaboration. 


\begin{tabular}{|c|c|c|c|c|}
\hline Category & $N$ & Mean & Std. error & $p$-value \\
\hline Doctors & 55 & 71.23 & 1.34 & $0.76^{*}$ \\
\hline Pharmacists & 09 & 84.21 & 1.98 & \\
\hline
\end{tabular}

* Not significant $p>0.05$.

Table 5. Group Statistics (doctors, pharmacists and
patients). Perception score on treatment outcome
\begin{tabular}{|l|l|l|l|l|}
\hline Category & N & Mean & Std. error & $p$-value \\
\hline Doctors & 55 & 19.87 & 0.3255 & $0.004^{*}$ \\
\hline Pharmacists & 09 & 20.4783 & 0.1872 & \\
\hline Patients & 100 & 17.965 & 0.2811 & \\
\hline
\end{tabular}

* Significant $(p<0.05)$.

\section{Study limitation}

The study gives an idea about the collaboration of doctor-pharmacist. However, it has some limitations. The sample size is small which provides a brief idea. To increase precision, the sample size may be increased.

\section{Discussion}

The demographic distribution of the patients cuts across the general population in terms of gender, occupation, educational status and age distribution which serve the purpose of the required sample. The patients showed more confidence and trust in pharmacists which corroborates the reference to pharmacists as "the most trusted" professionals and the rating of pharmacists above doctors in the list of Australia's most trusted professionals [15].

The patients indicated that doctors and pharmacists have separate roles in their management and that these roles are equally important and complementary. This indicates that they appreciate the difference in the roles of the professionals and role specification is noted to be a key factor that affects collaborative care and supports collaborative working relationship.

The demography for doctors and pharmacists show that they are experienced in practice, and experience has been shown to impact on the responses which influence the per- ception of a group.

Doctors showed more trust and confidence in pharmacists which corroborates the patients' response and they enjoy a good working relationship with the pharmacists.

The expansion of pharmacists' responsibilities beyond the dispensing role provides an avenue for them to use their clinical knowledge and specialized skills to assist the physician address the complexities of drug therapy in their roles as an interceptor, a detector and reporter for medication errors [16].

Most doctors and pharmacists strongly disagree that collaboration will waste time and add to treatment cost, the few that do not share the opinion may be thinking of increase time factor and human resource requirement that will invariably introduce additional costs to the organization. However the benefits of collaboration as expressed will justify such anticipated cost additions.

The willingness of the doctors and pharmacists to improve patient care will establish the basis and create the platform for the development of doctor-pharmacist collaborative patient care. Healthcare systems will be more effective when there is a willingness to facilitate collaboration among professionals.

\section{Conclusion}

The research revealed that patients have trust and confidence in the doctors and pharmacists whom they indicated collaborate in their care with roles equally important and complementary. They agreed that collaboration will reduce medication problems, mistakes and risks as well as improve the quality of care. Most of the doctors (65\%) strongly agree that they trust and enjoy working with the pharmacists. They agree that pharmacists share in the responsibility of patient management with equally important and complementary roles. They also agreed that collaboration will improve treatment outcome, quality of healthcare service and interdisciplinary relationship. Many $(78 \%)$ of the pharmacists moderately agree that they trust and have a good working relationship with the doctors, noting that patient management is a shared responsibility and believing that collaboration will improve treatment outcome, quality of service and interdisciplinary relationship.

\section{Acknowledgements}

We would like to thank all the staff and patients of district hospital for participating in the questionnaire.

Source of funding: This work was funded by the authors' resources.

Conflict of interest: The authors declare no conflict of interests.

\section{References}

1. Institute of Medicine. Creating safety systems in health care organizations. In: Kohn L, Corrigan J, Donaldson M, eds. To err is human: building a safer health system. Washington (DC): National Academy Press; 2000 [cited 09.06.2015]. Avaible from URL: http://books.nap.edu/html/to_err_is_human/exec_summ.html.

2. Hepler CD, Strand LM. Opportunities and responsibilities in pharmaceutical care. Am J Hosp Pharm 1990; 47(3): $533-543$.

3. Dolovich L, Kaczorowski J, Howard M, et al. Cardiovascular outcomes of a pharmaceutical care program integrated into family practices. Can J Clin Pharmacol 2007; 14(2): 116-122.

4. Carter BL, Ardery G, Dawson JD, et al. Physician and pharmacist collaboration to improve blood pressure control. Arch Intern Med 2009; 169(21): 1996-2002.

5. Dolovich L, Kaczorowski J, Sellors C, et al. Integration of a pharmaceutical care program into family practices: drug-therapy problems identified and recommendations made by participating pharmacists. Can J Clin Pharmacol 2007; 14(2): 164-171.

6. Sellors J, Kaczorowski J, Sellors C, et al. A randomized controlled trial of a pharmacist consultation program for family physicians and their elderly patients. CMAJ 2003; 169: 17-22.

7. Chen J, Britten N. 'Strong medicine': an analysis of pharmacist consultation in primary care. Fam Pract 2000; 17(6): 480-483.

8. Locca JF, Niquille A, Krähenbühl JM, et al. Physician-pharmacist collaboration: a way to improve the quality of drug prescribing. Rev Med Suisse 2009; 5(227): 2382-2384.

9. Zwarenstein M, Goldman J, Reeves S. Interprofessional collaboration: effects of practice based interventions on professional practice and healthcare outcomes. Cochrane Database Syst Rev 2009 [cited 09.06.2015]. Avaible from URL: http://www.ncbi. nlm.nih.gov/pubmed/19588316. 
10. Hemerson P, Izakovic M. Hospitalist-pharmacist collaboration. A success story of the integration of a clinical pharmacist on the multidisciplinary hospitalist team. Bratis/ Lek Listy 2011; 112(2): 88-91.

11. Roberts S, Gainsbrugh R. Medication therapy management and collaborative drug therapy management. J Manag Care Pharm 2010; 16(1): 67-68.

12. Carter BL, Ardery G, Dawson JD, et al. Physician and pharmacist collaboration to improve blood pressure control. Arch Intern Med 2009; 169(21): 1996-2002.

13. Liu Y, Doucette WR. Exploring stages of pharmacist-physician collaboration using the model of collaborative working relationship. J Am Pharm Assoc 2011; 51(3): 412-417.

14. Reader's Digest (2011); Australia's Most Trusted Professions: Reader's Digest Australia. Number 32 [cited 09.06.2015]. Avaible from URL: http://www.readersdigest.com.au/australiasmost- trusted-professions-2011.

15. Kucukarslan S, Lai S, Dong Y, et al. Physician beliefs and attitudes toward collaboration with community pharmacists. Res Social Adm Pharm 2011; 7(3): 224-232.

16. Tinelli M, Ryan M, Bond C. Patients' preferences for an increased pharmacist role in the management of drug therapy. Int J Pharm Pract 2009; 17(5): 275-282.

Address for correspondence:

Dr Mayur Porwal

IFTM University

244001 Moradabad, Uttar Pradesh

India

Tel.: +919719261023

E-mail: porwal_mayur1985@rediff.com

Received: 27.07.2015

Revised: 16.09.2015

Accepted: 18.09.2015 